\title{
Water quality prediction using the QUAL2Kw model in a small karstic watershed in Brazil
}

\author{
Predição da qualidade da água através do modelo QUAL2Kw \\ numa pequena bacia hidrográfica cárstica brasileira
}

Rodrigo de Arruda Camargo, Maria Lúcia Calijuri, Aníbal da Fonseca Santiago,

Eduardo de Aguiar de Couto and Marcos Dornelas Freitas Machado e Silva

Núcleo de Pesquisas Ambientais Avançadas - nPA, Departamento de Engenharia Civil, Universidade Federal de Viçosa - UFV, Av. P. H. Rolfs, s/n, CEP 36570-000, Viçosa, MG, Brazil e-mail: rodrigodeacamargo@gmail.com; calijuri@ufv.br; anibalsantiago@gmail.com; eduardo.acouto@hotmail.com; marcosdornelases@yahoo.com.br

\begin{abstract}
Aim: The Tancredo Neves International Airport (TNIA) complex is situated in Brazil's Fidalgo watershed. Since its construction, the TNIA complex has attracted urban development, leading to expansion of the complex and occupation of the surrounding area. However, this area lacks basic infrastructure such as wastewater treatment facilities. This paper had the objectives of calibrating and validating a water quality prediction model and of assessing the capacity of small karstic watersheds to assimilate non-point source pollutant loads; Methods: We used the QUAL2Kw model for modeling the water quality. We performed model calibration for the rainy period then validated the results for the dry period; Results: The model adequately represented the physical, chemical, and hydraulic aspects of the Fidalgo watershed. The $\mathrm{pH}, \mathrm{EC}$, TDS, TP, alkalinity and E. coli presented the closest simulation values for the rainy period. For the dry period, the best simulations were obtained for $\mathrm{pH}, \mathrm{EC}, \mathrm{TDS}$, TP, and alkalinity. We concluded that the calibration and validation periods had similar RMSE values for flow rate, TDS and DOC. The differences were greater for $\mathrm{pH}, \mathrm{EC}, \mathrm{NO}_{3}, \mathrm{TP}$, and $E$. coli. The lowest dissolved oxygen contents obtained during the calibration and validation periods were 5.4 and $4.7 \mathrm{mg} . \mathrm{L}^{-1}$, respectively, both of which are higher than the minimum of $4.0 \mathrm{mg} . \mathrm{L}^{-1}$ established by the USEPA for the conservation of aquatic communities, but lower than the minimum of $5.0 \mathrm{mg} . \mathrm{L}^{-1}$ established by the Brazilian CONAMA 357. The upper limits for biochemical oxygen demand and total $\mathrm{N}$ and $\mathrm{P}$ can be met as long as the respective loads increase by no more than $0.361 \mathrm{~kg} \cdot \mathrm{d}^{-1} \mathrm{O}_{2}, 0.022 \mathrm{~kg} . \mathrm{d}^{-1} \mathrm{~N}$, and $0.010 \mathrm{~kg} \cdot \mathrm{d}^{-1} \mathrm{P}$, according to USEPA and $0.361 \mathrm{~kg} . \mathrm{d}^{-1} \mathrm{O}_{2}$ and $0.012 \mathrm{~kg} \cdot \mathrm{d}^{-1} \mathrm{P}$ according to CONAMA 357; Conclusions: The conservation of the water resources in this region should therefore consider the adoption of preventive measures such as protecting exposed soils and decreasing the nutrient influx from agricultural and livestock activities.
\end{abstract}

Keywords: water quality, karstic region, modeling, QUAL2Kw, urban pollution.

Resumo: Objetivo: O Aeroporto Internacional Tancredo Neves (AITN) está localizado na microbacia do córrego do Fidalgo, Brasil. Desde sua construção, o AITN tem atraído a instalação de indústrias e loteamentos residenciais sem que a região oferecesse condiçôes básicas de infraestrutura. Este trabalho teve por objetivo calibrar e validar modelo de prediçấo da qualidade da água e avaliar a capacidade de assimilaçáo de cargas difusas em microbacia cárstica; Métodos: Utilizou-se o QUAL2Kw para a modelagem da qualidade da água. A calibração do modelo foi realizada no período chuvoso e a validaçáo para o período seco; Resultados: O modelo demonstrou ser capaz de representar com habilidade e flexibilidade os aspectos físicos, químicos e hidráulicos observados na microbacia. Os parâmetros $\mathrm{pH}, \mathrm{CE}, \mathrm{STD}, \mathrm{PT}$, alcalinidade e E. coli apresentaram os melhores ajustes entre as previsóes do modelo e os dados observados para o período chuvoso. Para o período seco, os melhores ajustes foram obtidos para $\mathrm{pH}, \mathrm{EC}, \mathrm{TDS}, \mathrm{TP} \mathrm{e}$ alcalinidade. Os valores de REMQ foram similares entre os períodos para vazão, SDT e $\mathrm{OD}$. As maiores diferenças foram observadas para os parâmetros $\mathrm{pH}, \mathrm{CE}, \mathrm{NO}_{3}, \mathrm{PT}$ e E. coli. O menor valor de OD obtido na calibração foi de $5,40 \mathrm{mg} \cdot \mathrm{L}^{-1}$ e na validação de 4,70 mg.L-1 , valores superiores ao mínimo estabelecido de $4,0 \mathrm{mg}$.L $\mathrm{L}^{-1}$ para conservação das comunidades aquáticas pela USEPA, porém inferior ao limite de 5,0 mg. $\mathrm{L}^{-1}$ estabelecido pela CONAMA 357.Os limites de DBO, NT e PT são atingidos com um acréscimo 
de carga na microbacia de $0,361 \mathrm{~kg} \cdot \mathrm{d}^{-1} \mathrm{O}_{2}, 0,022 \mathrm{~kg} \cdot \mathrm{d}^{-1} \mathrm{~N}$,e $0,010 \mathrm{~kg} \cdot \mathrm{d}^{-1} \mathrm{P}$ de acordo com a USEPA e $0,361 \mathrm{~kg} \cdot \mathrm{d}^{-1} \mathrm{O}_{2}$ e 0,012 kg. $\mathrm{d}^{-1} \mathrm{P}$ pela CONAMA 357; Conclusóes: A conservação dos recursos hídricos dessa região deve ser efetivada com a adoção de medidas preventivas, como a cobertura de solos expostos e a diminuiçáo do influxo de nutrientes de origem agrícola ou pecuária.

Palavras-chave: qualidade da água, região cárstica, modelagem, QUAL2Kw, poluição urbana.

\section{Introduction}

The urbanization process is a major factor that contributes to environmental problems such as floods, biodiversity loss and degradation of aquatic ecosystems (Fu et al., 2008). These impacts, which result from changes in land use or cover type and the intensification of human activities, generally cause changes in river hydraulic conditions, increases in non-point-source pollutant loads and the discharge of point-source pollutants, and reductions in base flow during droughts (Butler and Davies, 2004; Olivera and Defee, 2007).

Numerous studies have suggested that the quality of surface water is affected by the characteristics of the soil cover within a drainage area (Limburg and Schmidt, 1990; Jones et al., 1999; Bis et al., 2000; Riva-Murray et al., 2002; Woodcock et al., 2006; Chang, 2008). The deterioration of aquatic ecosystems results from decreases in the dissolved oxygen concentration (DOC) due to pollutant degradation by microorganisms, chemical oxidation, and plant, algal, and phytoplankton respiration (Drolc and Konkan, 1996). The impacts of low DOC or even of anaerobic conditions causes mortality of fish and other aquatic organisms, unpleasant odors, and other aesthetic damage (Cox, 2003).

Although it is possible to monitor the response of water quality to changes and impacts due to human activities, this approach is problematic because once a problem is detected, it may be difficult or impossible to be solved. A better alternative would be to estimate the impact of changes in anthropogenic discharges on a river's water quality using mathematical models, since that allows immediate remediation before problems become prohibitively difficult to solve. This practice has grown in popularity in recent years, and is becoming a common tool for the management of aquatic resources (Drolc and Konkan, 1996).

The use of mathematical models allows managers to represent alternative scenarios and simulate the real conditions that could result under these scenarios, within a range of uncertainty, based on scientific knowledge of how a river system responds to changes in its inputs. Thus, mathematical models of water quality are important simulation tools for obtaining representative knowledge of the river and predictions that will be consistent with reality under a range of scenarios (Tucci, 1998).

The establishment of the Tancredo Neves International Airport (TNIA) complex has changed the direction of urban growth in the metropolitan region of Belo Horizonte, Minas Gerais State, Brazil, and has resulted in considerable industrial and residential development despite the lack of basic infrastructure such as wastewater treatment plant. The establishment of the Minas Gerais state government administrative headquarters near the TNIA complex reinforced this growth trend. However, because this is a karstic region, the urbanization process in this area raises serious environmental concerns because of the low filtration capacity of the karst.

Williams (1993) noted that karstic environments are among the most fragile natural environments in the world, and are extremely susceptible to changes in their inputs. The high vulnerability to contamination is caused by the absence of filtering elements such as large bodies of sand and other sediments, which enables the contamination to assume alarming proportions when the pollutants are captured by underground conduit systems and transported over long distances.

This paper had the following objectives: i) to calibrate and validate a water quality prediction model; and ii) to assess the capacity of small karstic watersheds to assimilate non-point source pollutant loads, considering the limit values established by United States Environmental Protection Agency (USEPA) and the Brazilian CONAMA 357/2005 for the protection of aquatic communities in Class 2 rivers. We used the QUAL2Kw 2003 model (Chapra and Pelletier, 2003) modified by Pelletier et al. (2006), which is a one-dimensional steady-state system.

\section{Material and Methods}

\subsection{Study area}

The Fidalgo Stream watershed is located about $0.790 \mathrm{~km}$ from the TNIA complex, in 
the metropolitan region of Belo Horizonte, and lies within the Karstic Environmental Protection Area of Lagoa Santa (Figure 1). It covers an area of $7.12 \mathrm{~km}^{2}$, and our study examined the $4.2-\mathrm{km}$ length of the Fidalgo Stream.

According to the Köppen classification, the climate of Lagoa Santa and its surrounding plateau belongs to the Awi category. The annual precipitation averages $1286.5 \mathrm{~mm}$, with $82 \%$ of the total concentrated within the months from November to March. The altitude ranges from 718 to $847 \mathrm{~m}$ above sea level.

Since its construction in the 1970s, the TNIA complex has attracted urban development, leading to expansion of the complex and occupation of the surrounding area. The population growth rate was $3.9 \%$ in a year in the 1970 's, after the TNIA construction it increased to $5.5 \%$ per year (Silva et al., 2010). The establishment of residential areas within the watershed has changed the hydraulic regime of the Fidalgo Stream due to the construction of dams, which changed parts of the environment from a lotic state to a lentic state.

The main threats to water quality come from the lack of basic sanitation and inadequate planning of the urban and residential infrastructure. Primary and secondary recreation industries, livestock watering, sport fishing and irrigation of crops are the main water uses in the area.

\subsection{Water quality data}

The Fidalgo Stream represents a spring that emerges from the underlying karst structures towards the southern end of the study area. The monitoring stations presented in Figure 2 comprise four stations along the Fidalgo Stream and one station at its junction with a tributary.

Stations S1, S4, and T1 are lotic environments; the other stations are lentic. Station $S 1$ is located at a spring within a forest area. Station $\$ 4$ is located in a rural area of the municipality of Lagoa Santa and is predominantly surrounded by pastures and small fields of crops. Station T1 is in a residential area surrounded by green areas and riparian forest. Stations S2 and S3 are lentic environments that originated after impounding of the stream by the construction of dams in the residential areas.

To provide input data for the QUAL2Kw model, we calibrated the model using data from the rainy period, from 21 to 23 March 2009, and validated the model's predictions using data from the dry period, from 20 to 23 July 2009. Our choice of the month of March to represent the rainy period was due to the high rainfall index and the great influence of the contribution of diffuse load for the water quality. Similarly, our choice of the month of June to represent the dry period was due to the lower rainfall indices. Our choice of these distinct periods

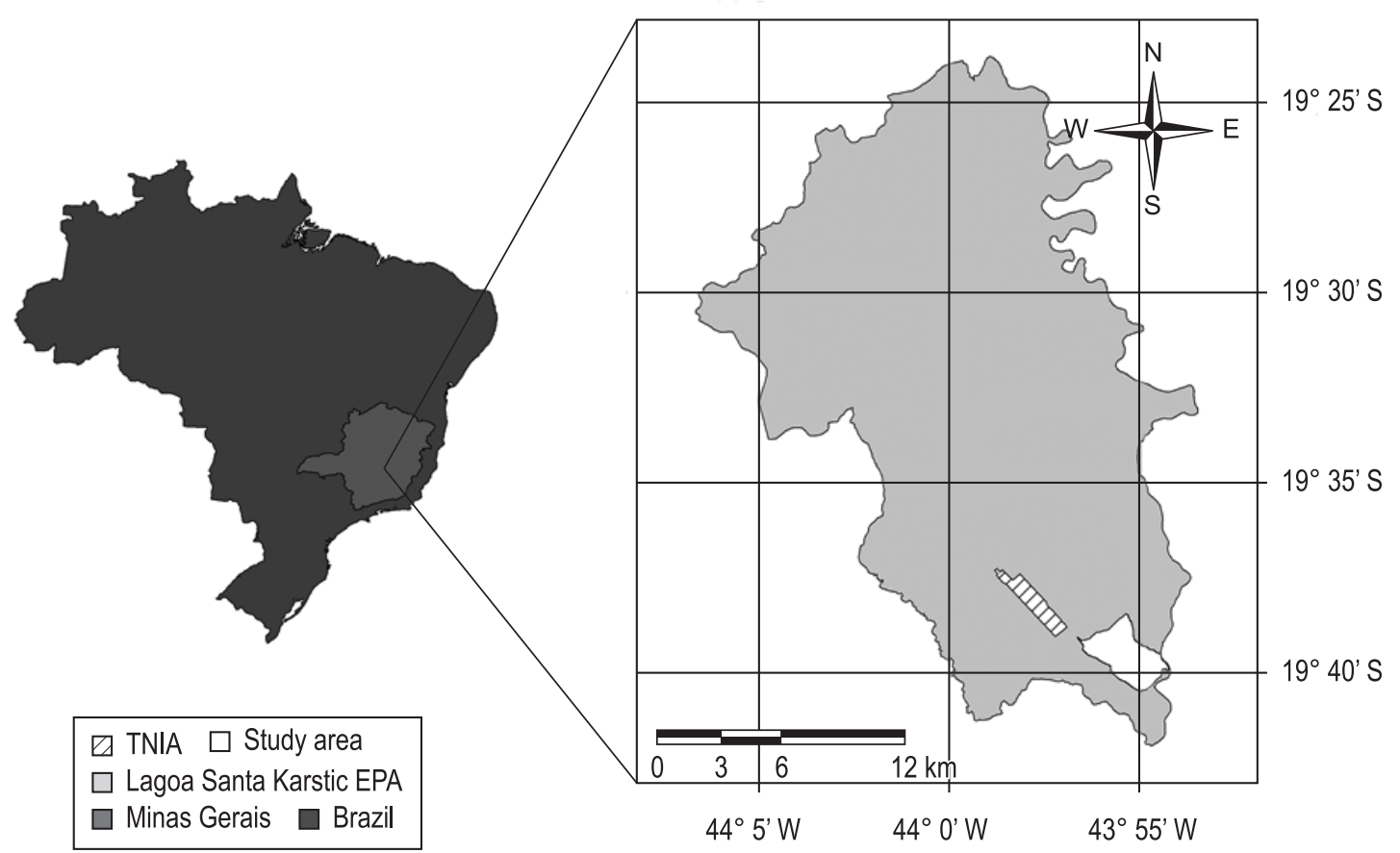

Figure 1. Location of the study area. 


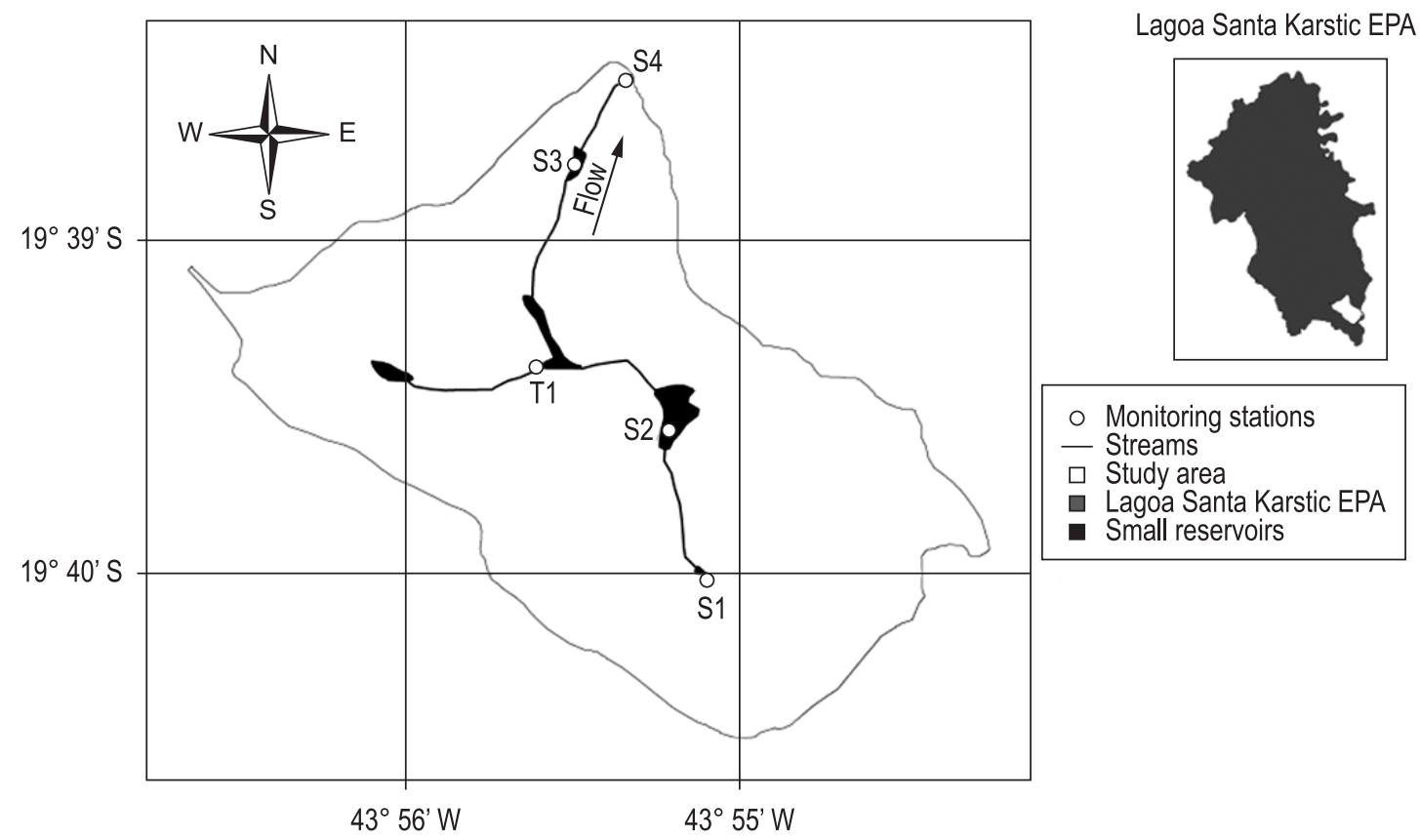

Figure 2. Location of the monitoring stations along the Fidalgo Stream and tributary.

for calibration and validation had the objective of validating the model's applicability during two times of the year with strongly different water flow characteristics. The field work consisted of collecting one sample per monitoring station in each of the two study periods.

The physiochemical and microbiological variables measured in this study were the flow rate, $\mathrm{pH}$, electrical conductivity (EC), DOC, total dissolved solids (TDS), total alkalinity, organic nitrogen $\left(\mathrm{N}_{\mathrm{org}}\right)$, ammonia nitrogen $\left(\mathrm{NH}_{3}\right)$, nitrate nitrogen $\left(\mathrm{NO}_{3}\right)$, total phosphorus (TP), 5-day biochemical oxygen demand $\left(\mathrm{BOD}_{5}\right)$, and Escherichia coli count (E. coli), which served as an indicator of fecal contamination. The water samples were collected, transported, and analyzed according to the methods of APHA et al. (1995) and USGS (1974).

\subsection{QUAL2Kw model}

The QUAL2Kw is a model for the simulation of water quality in rivers and streams, distributed by the USEPA. The QUAL2Kw model is based on ordinary differential equations for one-dimensional systems and an assumption of constant flow. The QUAL2Kw can simulate a number of constituents including temperature, $\mathrm{pH}$, carbonaceous biochemical demand, sediment oxygen demand, dissolved oxygen, organic nitrogen, ammonia nitrogen, nitrite and nitrate nitrogen, organic phosphorus, inorganic phosphorus, total nitrogen, total phosphorus, phytoplankton and bottom algae.

The user can choose between a permanent or a dynamic flow condition. We chose the dynamic condition because the model allows the simulation of each water quality parameter along the watercourse. On this basis, it is possible to perform mass-balance calculations for each constituent of the model, except for variables related to river-bottom algae. The reach is considered to be a complete mix reactor, and the succession by the following elements allows the model to represent the evolution of the water quality along the river (Pelletier et al., 2006). Figure 3 illustrates the mass-balance scheme used as the computational element in the model. The general mass-balance equation for a constituent concentration $\mathrm{c} i$ in the water column (excluding hyporheic) of a reach i (the transport and loading terms are omitted from the mass-balance equation for bottom algae modeling) as (Equation 1):

$$
\begin{aligned}
& \frac{d_{c i}}{d_{t}}=\frac{Q_{i}-1}{V_{i}} C_{i-1}-\frac{Q_{i}}{V_{i}} C_{i}-\frac{Q_{a b, i}}{V_{i}} C_{i}+\frac{E_{i}-1}{V_{i}}\left(C_{i-1}-C_{i}\right) \\
& +\frac{E_{i}}{V_{i}}\left(C_{i+1}-C_{i}\right)+\frac{W_{i}}{V_{i}}+S_{i}
\end{aligned}
$$

where $\mathrm{Q} i=$ flow at reach $\mathrm{i}(\mathrm{L} /$ day $), \mathrm{Q}_{\mathrm{ab}}, \mathrm{i}=$ abstraction flow at reach $i(\mathrm{~L} /$ day $), \mathrm{Vi}=$ volume of reach $\mathrm{i}(\mathrm{L})$, $\mathrm{Wi}=$ the external loading of the constituent to reach $\mathrm{i}(\mathrm{mg} /$ day), $\mathrm{Si}=$ sources and sinks of the constituent due to reactions and mass transfer mechanisms $(\mathrm{mg} / \mathrm{L} /$ day $), \mathrm{Ei}=$ bulk dispersion coefficient 
between reaches (L/day), $\mathrm{E}_{\mathrm{i}-1}$, Ei are bulk dispersion coefficients between reaches $\mathrm{i}-1$ and $\mathrm{i}$ and $\mathrm{i}$ and $\mathrm{i}+1$ (L/day), $\mathrm{ci}=$ concentration of water quality constituent in reach $\mathrm{i}(\mathrm{mg} / \mathrm{L})$ and $\mathrm{t}=$ time (day).

Figure 4 represents the schematic diagram of interacting water quality state variables. The complete description of the process of interacting water quality state variables is available in Pelletier and Chapra (2005).

For auto-calibration, the model uses a genetic algorithm to maximize the adjustment of the simulated results based on data measured in the field. The fitness is determined as the reciprocal of the weighted average of the normalized root mean square error (RMSE) of the difference between the model predictions and the observed data for water quality constituents (Kannel et al., 2007).

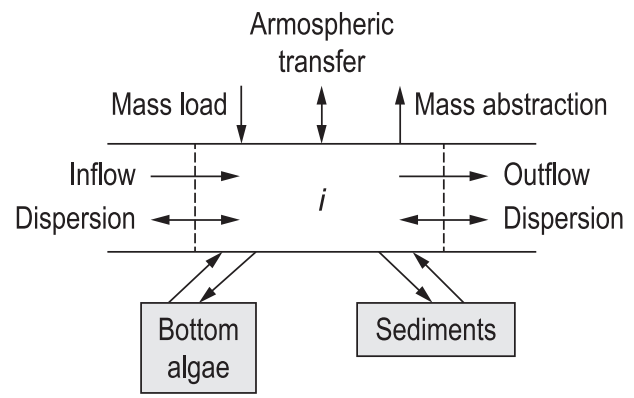

Figure 3. Mass-balance in a reach segment $I$ (adapted from Pelletier and Chapra, (2005)).

\subsection{Model calibration and validation}

\subsubsection{Stream discretization}

The selected $4.2 \mathrm{~km}$ of the Fidalgo stream was discretized into 41 reaches. Figure 5 shows the stream segmentation system and the location of the tributary input.

\subsubsection{Input data}

The model allows the use of input data for the hydraulic characteristics of each river reach. We used the Manning equation (Equation 2) to obtain the following characteristics: mean velocity and depth as a function of the stream's width, bottom declivity, slopes, and Manning roughness coefficient (Pelletier et al., 2006).

$\mathrm{Q}=\frac{\mathrm{S}_{0}^{1 / 2}}{\mathrm{n}} \frac{\mathrm{A}_{\mathrm{C}}^{5 / 3}}{\mathrm{p}^{2 / 3}}$

where $\mathrm{Q}=$ flow $\left[\mathrm{m}^{3} / \mathrm{s}\right], \mathrm{S}_{0}=$ bottom slope $[\mathrm{m} / \mathrm{m}]$, $\mathrm{n}=$ the Manning roughness coefficient, $\mathrm{Ac}=$ the cross-sectional area $\left[\mathrm{m}^{2}\right]$, and $\mathrm{P}=$ the wetted perimeter $[\mathrm{m}]$. The sets of reaches between the four main monitoring stations (1-14, 15-29, 30-36, and 37-41) and their respective hydraulic characteristics are presented in Table 1 . Notice that time is measured in "seconds" in this and other formulas used to characterize hydraulics. This is how the computations are implemented within QUAL2Kw. However, once the hydraulic characteristics are

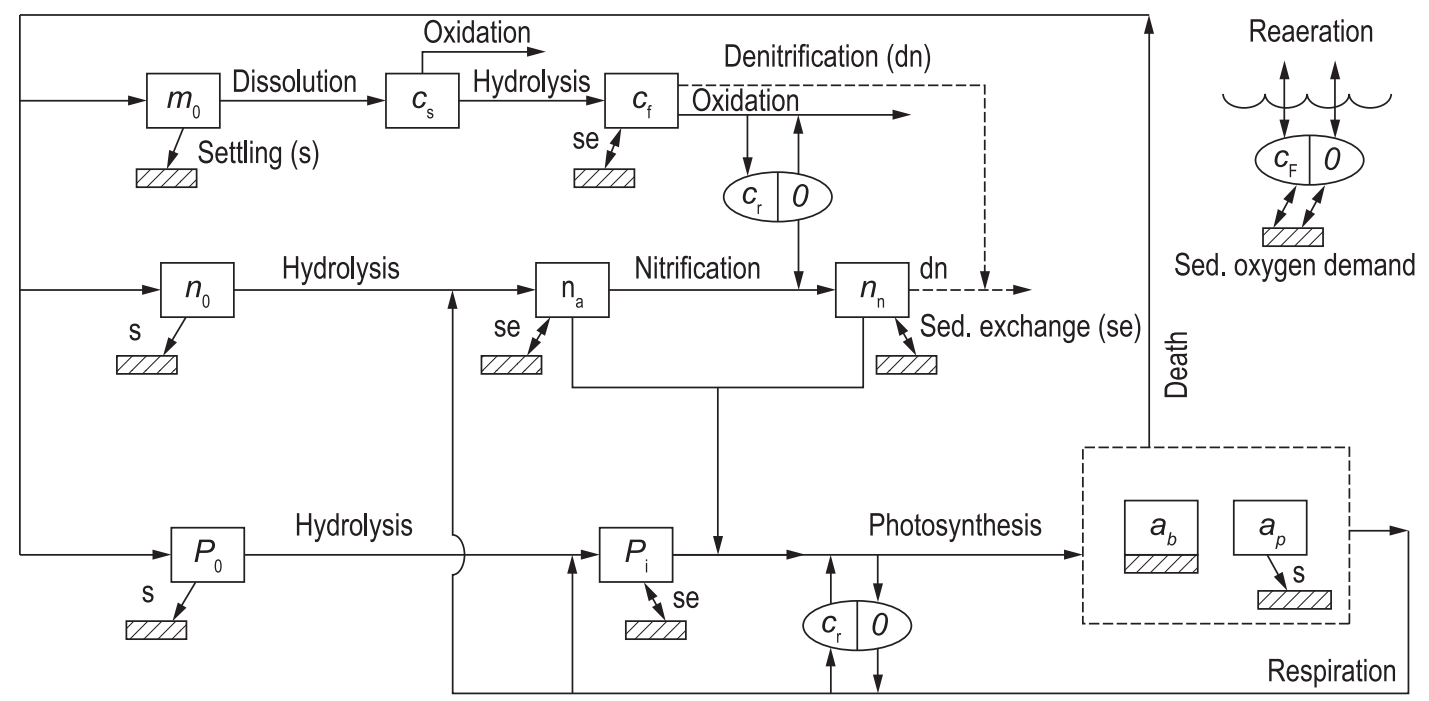

Figure 4. Schematic diagram of interacting water quality state parameters, $a_{b}$ : bottom algae, $a_{p}$ : phytoplankton, $m_{o}$ : detritus, $c_{s}$ : slow $C B O D, c_{\mathrm{f}}$ fast $C B O D, c_{T}$ : total inorganic carbon, o: oxygen, $n_{o}$ : organic nitrogen, $n_{a}$ : ammonia nitrogen, $\mathrm{n}_{\mathrm{n}}$ : nitrate nitrogen, $\mathrm{p}_{\mathrm{o}}$ : organic phosphorus and $\mathrm{p}_{\mathrm{i}}$ : inorganic phosphorus (adapted from Kannel et al., (2007)). 
determined they are converted to "days" to be compatible with other computations.

The input water quality parameters included in the model were the flow rate, $\mathrm{pH}$, TDS, EC, DOC, $\mathrm{BOD}_{5}, \mathrm{~N}_{\text {org }}, \mathrm{NH}_{3}, \mathrm{NO}_{3}$, total phosphorus, alkalinity, and $E$. coli count. The algae cover and bottom-sediment oxygen demand were both assumed to be $100 \%$ (Kannel et al., 2007). The sediment/hyporheic zone thickness, sediment porosity and hyporheic exchange flow were assumed to be $10 \mathrm{~cm}, 40 \%$, and $5 \%$, respectively (Kannel et al., 2007). The reaches were characterized based on the contributions of point and non-point sources. The effluent stream was considered to be a point source, and its water quality parameters and flow data were incorporated into the model.

The meteorological data required for the modeling were obtained from the TNIA meteorological station. We obtained values for air temperature, wind speed, and the percentage of cloud cover for the periods when samples were collected.

\subsubsection{Kinetics parameters}

Table 2 presents the kinetics parameters recommended in the literature and used in the model calibration process (Pelletier and Chapra, 2005; Brown and Barnwell Junior, 1987).

We used nonlinear regression to calculate the deoxygenation coefficient $\left(\mathrm{K}_{1}\right)$. To obtain $\mathrm{K}_{1}$ and $\mathrm{BODu}$, we adjusted a theoretical curve to fit the
BOD values found for the samples collected in different days (Von Sperling, 2007). In this case, we used days $1,3,5,9,15$ e 21 . For each of the reaches considered in the model, we modified the Streeter-Phelps equation to calculate the value of the reaeration coefficient $\left(\mathrm{K}_{2}\right)$ according to Equation 3 (Lima, 2005):

$$
\begin{aligned}
& \mathrm{OD}_{\mathrm{f}}=\mathrm{OD}_{\text {sat }}-\frac{\mathrm{K}_{1}}{\mathrm{~K}_{2}-\left(\mathrm{K}_{1}+\mathrm{K}_{3}\right)}\left(\mathrm{L}_{0}-\frac{\mathrm{L}_{\mathrm{a}}}{\mathrm{K}_{1}+\mathrm{K}_{3}}\right) \\
& \left(\mathrm{e}^{-\left(\mathrm{K}_{1}+\mathrm{K}_{3}\right) \mathrm{t}}-\mathrm{e}^{-\mathrm{K}_{2} \mathrm{t}}\right)+\frac{\mathrm{K}_{1} \mathrm{~L}_{\mathrm{a}}}{\mathrm{K}_{2}\left(\mathrm{~K}_{1}+\mathrm{K}_{3}\right)}\left(1-\mathrm{e}^{-\mathrm{k}_{2} \mathrm{t}}\right)+\mathrm{De}^{-\mathrm{K}_{2} \mathrm{t}}
\end{aligned}
$$

Table 3 presents the resulting values of $K_{1}$ and $\mathrm{K}_{2}$ used for each reach.

We chose QUAL2Kw's exponential model for oxygen inhibition due to BOD oxidation, nitrification, denitrification, and respiration by bottom algae and aquatic plants. The other parameters were the defaults recommended by QUAL2Kw.

\subsubsection{Model implementation}

We used data obtained during the rainy season to calibrate the model. The calculation time step used for the calculations was fixed at 1.40625 minutes to avoid instability in the model. We performed the integration using Euler's method; for the $\mathrm{pH}$ modeling, we used the Newton-Raphson method.

To simulate exchanges in the hyporheic zone, we chose level I in the model, because it included zeroorder and first-order oxidation of the fast-reacting

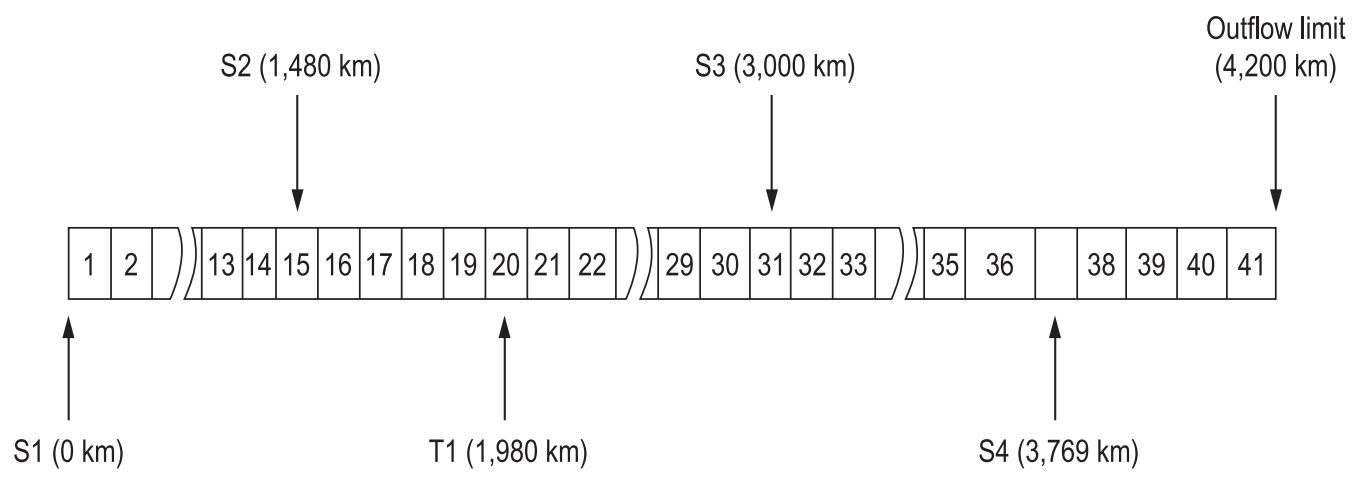

Figure 5. Discretization of the Fidalgo stream.

Table 1. Hydraulic characteristics of the monitoring Stations along the Fidalgo stream.

\begin{tabular}{ccccccc}
\hline Location & $\begin{array}{c}\text { Reaches } \\
\text { (Fig. 4) }\end{array}$ & $\begin{array}{c}\text { Channel slope } \\
(\mathrm{m} / \mathrm{m})\end{array}$ & $\begin{array}{c}\text { Manning's } \\
\text { coefficient }(\mathrm{n})\end{array}$ & $\begin{array}{c}\text { Channel width } \\
(\mathrm{m})\end{array}$ & $\begin{array}{c}\text { Left bank } \\
(\mathrm{m})\end{array}$ & $\begin{array}{c}\text { Right bank } \\
(\mathrm{m})\end{array}$ \\
\hline 0,000 & $0-14$ & 0.0061 & 0.07 & 0.3 & 0.00 & 0.00 \\
1,480 & $15-29$ & 0.0046 & 0.07 & 0.3 & 0.00 & 0.00 \\
3,000 & $30-36$ & 0.0169 & 0.07 & 0.3 & 1.08 & 1.00 \\
3,769 & $37-41$ & 0.0020 & 0.07 & 0.3 & 0.43 & 0.00 \\
\hline
\end{tabular}


Table 2. Kinetics parameters used in modeling of the Fidalgo Stream.

\begin{tabular}{|c|c|c|c|c|c|}
\hline Parameter & Value & Units & $\begin{array}{c}\text { Auto- } \\
\text { calibration }\end{array}$ & $\begin{array}{l}\text { Minimum } \\
\text { value }\end{array}$ & $\begin{array}{l}\text { Maximum } \\
\text { value }\end{array}$ \\
\hline \multicolumn{6}{|l|}{ Stoichiometry } \\
\hline Carbon & 40 & $g C$ & No & 30 & 50 \\
\hline Nitrogen & 7.2 & $g N$ & No & 3 & 9 \\
\hline Phosphorus & 1 & $g P$ & No & 0.4 & 2 \\
\hline Dry weight & 100 & $g D$ & No & 100 & 100 \\
\hline Chlorophyll & 1 & $g A$ & No & 0.4 & 2 \\
\hline \multicolumn{6}{|l|}{ Inorganic suspended solids } \\
\hline Settling velocity & 0.3938 & $m \cdot d^{-1}$ & Yes & 0 & 2 \\
\hline \multicolumn{6}{|l|}{ Organic nitrogen } \\
\hline Hydrolysis & 3.457 & $d^{-1}$ & Yes & 0 & 5 \\
\hline Settling velocity & 0.42036 & $m \cdot d^{-1}$ & Yes & 0 & 2 \\
\hline \multicolumn{6}{|l|}{ Ammonia nitrogen $\left(\mathrm{NH}_{3}\right)$} \\
\hline Nitrification & 9.919 & $d^{-1}$ & Yes & 0 & 10 \\
\hline \multicolumn{6}{|l|}{ Nitrate $\left(\mathrm{NO}_{3}\right)$} \\
\hline Denitrification & 0.00314 & $d^{-1}$ & Yes & 0 & 2 \\
\hline $\begin{array}{l}\text { Sediment denitrification transfer coefficient } \\
\text { Organic phosphorus }\left(\mathrm{P}_{\text {orro }}\right)\end{array}$ & 0.21261 & $m \cdot d^{-1}$ & Yes & 0 & 1 \\
\hline Hydrolysis & 1.4742 & $d^{-1}$ & Yes & 0 & 2 \\
\hline Settling velocity & 1.0932 & $m \cdot d^{-1}$ & Yes & 0 & 2 \\
\hline \multicolumn{6}{|l|}{ Inorganic phosphorus $\left(\mathrm{P}_{\text {inorg }}\right)$} \\
\hline Settling velocity & 1.97116 & $m \cdot d^{-1}$ & Yes & 0 & 2 \\
\hline $\begin{array}{l}\text { Sediment oxygen attenuation, half-saturation } \\
\text { constant }\end{array}$ & 1.18454 & $\mathrm{mg} \mathrm{O}_{2} \cdot \mathrm{L}^{-1}$ & Yes & 0 & 2 \\
\hline \multicolumn{6}{|l|}{ E. coli } \\
\hline Decay rate & 1.9943 & $d^{-1}$ & Yes & 0 & 5 \\
\hline Settling velocity & 4.80405 & $m \cdot d^{-1}$ & Yes & 0 & 5 \\
\hline $\begin{array}{l}\text { Alpha constant for fish light mortality } \\
\mathrm{pH}\end{array}$ & 0.10692 & ly. $(h r . d)^{-1}$ & Yes & 0 & 3 \\
\hline Carbon dioxide partial pressure & 347 & Ppm & - & - & - \\
\hline
\end{tabular}

Table 3. Kinetics parameters at the monitoring Stations along the Fidalgo stream.

\begin{tabular}{cccc}
\hline $\begin{array}{c}\text { Location } \\
(\mathrm{km} \text { from S1) }\end{array}$ & Reaches & $\mathrm{K}_{1}$ & $\mathrm{~K}_{2}$ \\
\hline 0,000 & $0-14$ & 0.313 & 0.175 \\
1,480 & $15-29$ & 0.141 & 0.496 \\
3,000 & $30-36$ & 0.196 & 0.667 \\
3,769 & $37-41$ & 0.184 & 0.581 \\
\hline
\end{tabular}

dissolved components of BOD. To obtain the best adjustment, the modeling system assigns standard weights to various parameters so as to minimize the error between the observed and simulated data. We used a weight of 50 for DOC, because it is the most influential parameter, versus weights of two for $\mathrm{pH}, \mathrm{BOD}_{5}, \mathrm{~N}_{\mathrm{org}}, \mathrm{NH}_{3}, \mathrm{NO}_{3}, \mathrm{P}_{\text {org }}$, and $\mathrm{P}_{\text {inorg }}$; the other parameters received a weight of 1 (Kannel et al., 2007).

The genetic algorithm was run for a population size of 100, with 50 generations of evolution, until we obtained only minor differences between the simulated results and the observed data. According to Pelletier et al. (2006), a population of 100 performs better than smaller numbers and nearly as well as a population of 500 .

To test the model's ability to predict the water quality conditions during different hydrological periods, we ran the model again for the dry period, without changing the parameters that were calibrated for the rainy period. Next, we used the model to simulate the water quality under different assumed changes (scenarios) in the watershed's inputs during the rainy period. 


\section{Results and Discussion}

\subsection{Calibration and validation of the water quality model}

Table 4 summarizes the field water quality measurements during the rainy period, from 21 to 23 March 2009. Figure 6 shows the simulated values of the monitored parameters for the Fidalgo Stream.

Figure 6 shows that the water quality at the spring (site S1) did not differ greatly from the values at Stations farther downstream for $\mathrm{pH}$, DOC, and $\mathrm{NH}_{3}$. However, the EC, TDS, TP, alkalinity, and $E$. coli values were highest at the spring, and decreased with increasing distance downstream. The spring is characterized by a small lake where cattle and goats are constantly observed (i.e., these animals are watered here), and this probably affected the water quality at this station, particularly in terms of the phosphorus concentration and E. coli count.

Kohler (1989) noted that the dissolution of limestone in karstic environments increases the amount of dissolved ions in the water, and particularly those of carbonates and bicarbonates. These ions subsequently combine with other dissolved compounds, leading to a decrease in their concentration with increasing distance from the source. Thus, because underground water emerges in the spring at site $\mathrm{S} 1$, EC and alkalinity were highest at this station.

Table 5 summarizes the water quality results measured in the field during the dry period, from 20 to 23 July 2009. Figure 7 presents the simulated values of the monitored parameters for the Fidalgo Stream during this period. The validation results for the dry period were similar to those for the rainy period, with little variation in $\mathrm{pH}, \mathrm{DOC}$, and
$\mathrm{NH}_{3}$, and a decrease in EC, TDS, TP, and alkalinity with increasing distance from the spring. However, E. coli remained largely constant, except for a large increase at a distance of $2 \mathrm{~km}$; this increase likely resulted from the fact that the tributary (T1) enters the stream at this station.

\subsection{Root-mean-square error (RMSE)}

Table 6 summarizes the RMSE values obtained by the minor difference between the model's predictions and the observed data for the calibration period (the rainy season) and the validation period (the dry season). Table 6 also includes RMSE values from previous studies to provide a comparison with the present results. Kannel et al. (2007) studied Nepal's Bagmati River, and found a good match between the observed and predicted values for flow rate $($ RMSE $=4.0 \%)($ Table 6$)$ and a poor match for BOD (RMSE $=20.8$ to $52.0 \%$ ). The drainage area in their paper is part of a populous urban watershed subject to the discharge of industrial, domestic, and hospital effluents, with high loads of organic matter and nutrients, and a low DOC concentration throughout the stream. Guedes et al. (2009) studied the Pomba River in Brazil and found a good match between predicted and observed values for $\mathrm{BOD}(\mathrm{RMSE}=4.2 \%)$ (Table 6) but not for DOC $(\mathrm{RMSE}=10.8 \%)$. This may be because they studied a rural watershed, with little industrial development. The deterioration of water quality results from the discharge of untreated domestic sewage into the water.

The $\mathrm{pH}, \mathrm{EC}, \mathrm{TDS}, \mathrm{TP}$, alkalinity and E. coli presented the closest simulation values for the rainy period. For the dry period, the best simulations were obtained for $\mathrm{pH}, \mathrm{EC}, \mathrm{TDS}, \mathrm{TP}$, and alkalinity. We concluded that the calibration and validation

Table 4. Water quality parameters measured along the Fidalgo Stream and tributary during the rainy period.

\begin{tabular}{|c|c|c|c|c|c|c|}
\hline $\begin{array}{l}\text { Monitoring } \\
\text { station }\end{array}$ & $\begin{array}{c}\text { Flow rate } \\
\left(\mathrm{m}^{3} \cdot \mathrm{s}^{-1}\right)\end{array}$ & $\mathrm{pH}$ & $\begin{array}{c}\text { EC } \\
\left(\mu S . \mathrm{cm}^{-1}\right)\end{array}$ & $\begin{array}{c}\text { TDS } \\
\left(\mathrm{mg} \cdot \mathrm{L}^{-1}\right)\end{array}$ & $\begin{array}{c}\text { DOC } \\
\left(\mathrm{mg} \cdot \mathrm{L}^{-1}\right)\end{array}$ & $\begin{array}{c}\mathrm{BOD}_{5} \\
\left(\mathrm{mg} \cdot \mathrm{L}^{-1}\right)\end{array}$ \\
\hline S1 & 0.0029 & 7.11 & 320.3 & 186.67 & 5.70 & 0.17 \\
\hline S2 & 0.0525 & 7.34 & 157.1 & 104.55 & 6.25 & 2.99 \\
\hline S3 & 0.1068 & 7.29 & 140.0 & 97.73 & 5.40 & 0.58 \\
\hline S4 & 0.1014 & 6.68 & 140.1 & 95.91 & 6.60 & 0.77 \\
\hline $\mathrm{T} 1$ & 0.0165 & 7.73 & 51.4 & 32.27 & 6.60 & 1.00 \\
\hline $\begin{array}{l}\text { Monitoring } \\
\text { station }\end{array}$ & $\begin{array}{c}\mathrm{N}_{\text {org }} \\
\left(\mathrm{mg} \cdot \mathrm{L}^{-1}\right)\end{array}$ & $\begin{array}{c}\mathrm{NH}_{3} \\
\left(\mathrm{mg} \cdot \mathrm{L}^{-1}\right)\end{array}$ & $\begin{array}{c}\mathrm{NO}_{3} \\
\left(\mathrm{mg} \cdot \mathrm{L}^{-1}\right)\end{array}$ & $\begin{array}{c}\text { TP } \\
\left(m g . L^{-1}\right)\end{array}$ & $\begin{array}{l}\text { Alkalinity } \\
\left(\mathrm{mg} \cdot \mathrm{L}^{-1}\right)\end{array}$ & $\begin{array}{c}\text { E. coli } \\
(\text { CFU.100 mL-1) }\end{array}$ \\
\hline S1 & 0.11 & 0.17 & 0.08 & 0.058 & 171.45 & 500 \\
\hline S2 & 0.10 & 0.14 & 0.04 & 0.016 & 87.16 & 12 \\
\hline S3 & 0.24 & 0.14 & 0.15 & 0.017 & 74.99 & 80 \\
\hline S4 & 0.11 & 0.09 & 0.11 & 0.016 & 78.79 & 100 \\
\hline $\mathrm{T} 1$ & 0.10 & 0.09 & 0.01 & 0.040 & 47.27 & 300 \\
\hline
\end{tabular}



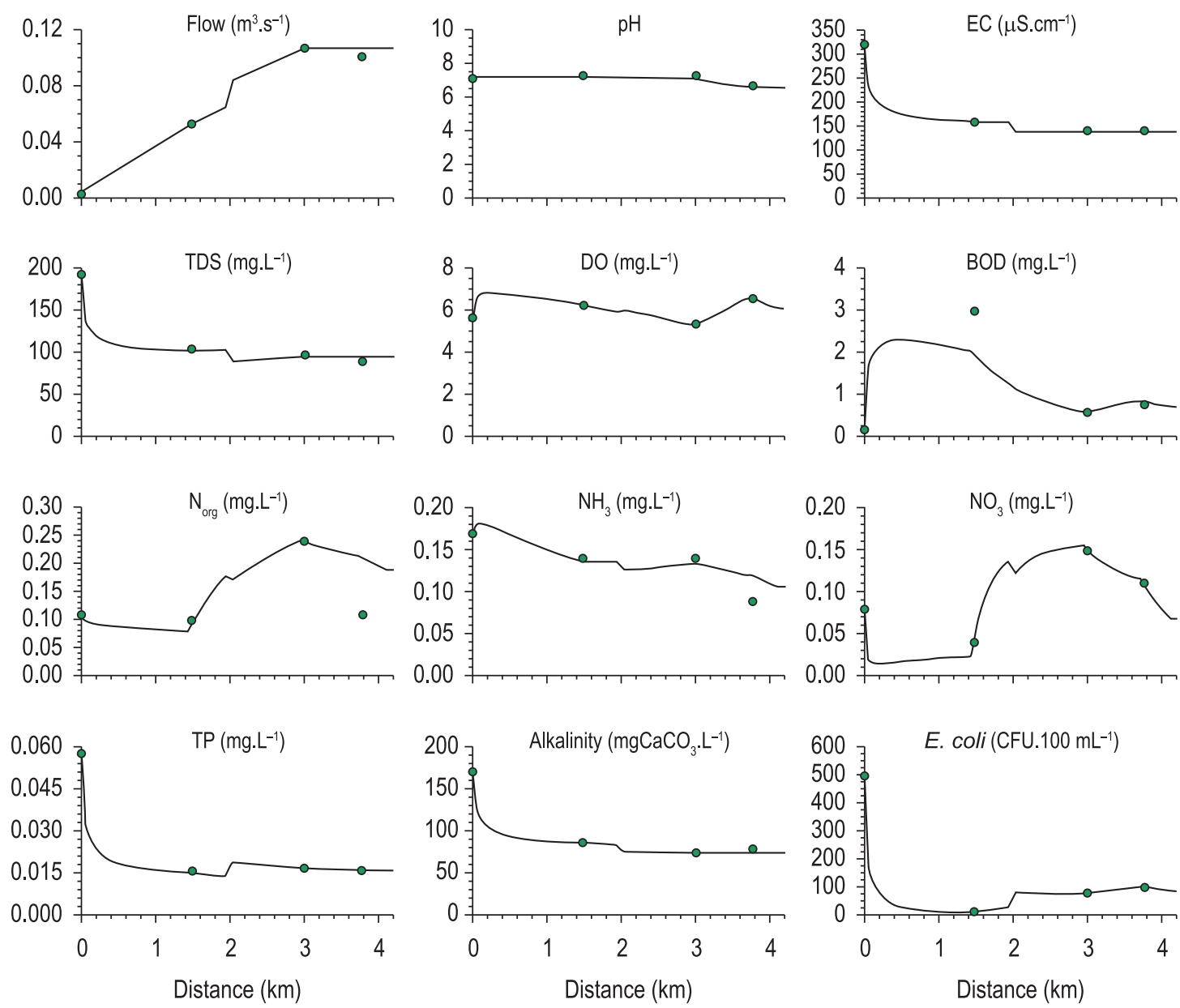

Figure 6. Model calibration results for the water quality parameters in the Fidalgo Stream using the rainy season data.

Table 5. Water quality parameters measured along the Fidalgo Stream and tributary during the dry period.

\begin{tabular}{|c|c|c|c|c|c|c|}
\hline $\begin{array}{l}\text { Monitoring } \\
\text { station }\end{array}$ & $\begin{array}{c}\text { Flow rate } \\
\left(\mathrm{m}^{3} \cdot \mathrm{s}^{-1}\right)\end{array}$ & $\mathrm{pH}$ & $\begin{array}{c}\text { EC } \\
\left(\mu \mathrm{s} . \mathrm{cm}^{-1}\right)\end{array}$ & $\begin{array}{c}\text { TDS } \\
\left(\mathrm{mg} \mathrm{LL}^{-1}\right)\end{array}$ & $\begin{array}{c}\text { DOC } \\
\left(m g . L^{-1}\right)\end{array}$ & $\begin{array}{l}\mathrm{BOD}_{5} \\
\left(\mathrm{mg}^{-\mathrm{L}^{-1}}\right)\end{array}$ \\
\hline S1 & 0.0010 & 7.28 & 358.6 & 157.20 & 5.2 & 0.80 \\
\hline S2 & 0.0184 & 7.56 & 198.2 & 97.00 & 7.3 & 2.33 \\
\hline S3 & 0.0375 & 7.69 & 183.2 & 101.00 & 6.3 & 0.44 \\
\hline S4 & 0.0356 & 7.44 & 169.1 & 106.50 & 4.7 & 0.11 \\
\hline $\mathrm{T} 1$ & 0.0058 & 7.73 & 66.4 & 40.50 & 7.40 & 0.44 \\
\hline $\begin{array}{l}\text { Monitoring } \\
\text { station }\end{array}$ & $\underset{\left(m g \cdot L^{-1}\right)}{N_{\text {org }}}$ & $\begin{array}{c}\mathrm{NH}_{3} \\
\left(\mathrm{mg} \cdot \mathrm{L}^{-1}\right)\end{array}$ & $\begin{array}{c}\mathrm{NO}_{3} \\
\left(\mathrm{mg}^{-\mathrm{L}^{-1}}\right)\end{array}$ & $\begin{array}{c}\mathrm{TP} \\
\left(\mathrm{mg} \cdot \mathrm{L}^{-1}\right)\end{array}$ & $\begin{array}{l}\text { Alkalinity } \\
\left(\mathrm{mg} \cdot \mathrm{L}^{-1}\right)\end{array}$ & $\begin{array}{c}\text { E. coli } \\
\left.\text { (CFU.100 } \mathrm{mL}^{-1}\right)\end{array}$ \\
\hline S1 & 0.30 & 0.18 & 0.04 & 0.057 & 167.00 & 1 \\
\hline S2 & 0.22 & 0.21 & 0.01 & 0.013 & 93.00 & 1 \\
\hline S3 & 0.27 & 0.16 & 0.03 & 0.018 & 84.00 & 2 \\
\hline S4 & 0.21 & 0.18 & 0.01 & 0.016 & 79.50 & 1 \\
\hline T1 & 0.22 & 0.15 & 0.01 & 0.027 & 28.00 & 28 \\
\hline
\end{tabular}

periods had similar RMSE values when the two values differed by less than $20 \%$ of the RMSE for the calibration period. On this basis, the RMSE values were similar for flow rate, TDS and DOC. The differences were greater for $\mathrm{pH}, \mathrm{EC}, \mathrm{NO}_{3}$, TP, and E. coli. These differences can be attributed to changes in environmental conditions between the two periods. During the rainy period, the values of many parameters were higher than the corresponding values during the dry period (Tables 4,5 ) because in the study area, the nonpoint-source inputs that resulted from rainfall 

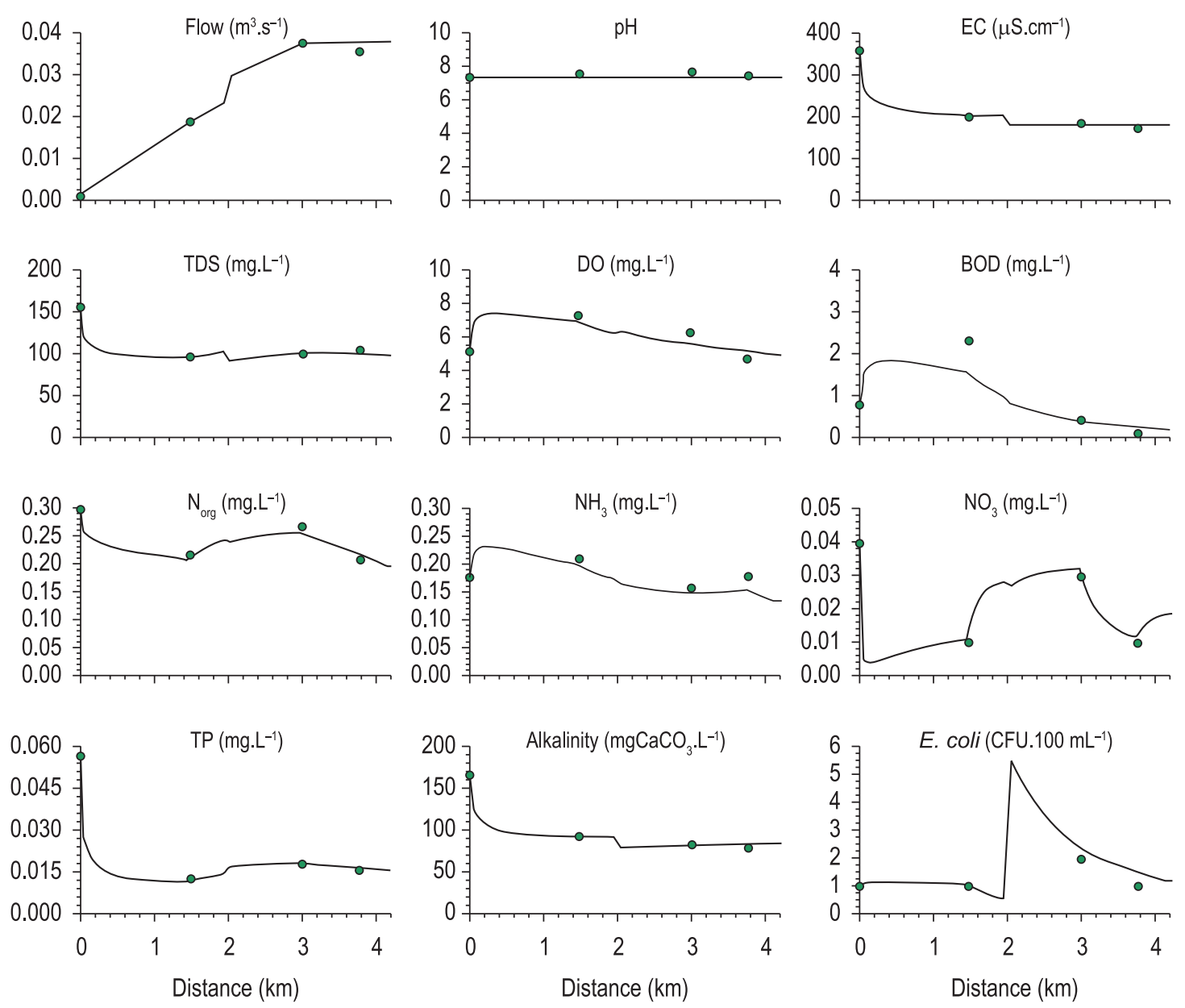

Figure 7. Model validation for the water quality parameters in the Fidalgo Stream using the dry season data.

increase during the rainy period and significantly influence the water quality.

$\mathrm{BOD}_{5}$ was the parameter with the greatest difference between the simulated and observed data (RMSE values $>45.0 \%)$. During the rainy period, the simulated values at S3 and S4 were higher than the values measured in the field, which did not happen for stations S1 and S2. It is possible that the change from a lotic environment to a lentic environment in the simulated reaches was responsible for this difference, since stations S1 and S2 were predominantly lotic and stations S3 and S4 were predominantly lentic. It is also possible that inputs from the tributary affected the water characteristics downstream from where it enters the Fidalgo Stream, and the model does not satisfactorily represent this parameter.

Small reservoirs along a river tend to act as stabilization ponds, and assist in the natural purification of a river. Von Sperling (2007) explains that lentic environments promote a decrease in
BOD because the suspended organic matter tends to settle out, becoming part of the bottom sediments and retaining only dissolved organic matter and some small-diameter suspended organic matter in the water that leaves the lake.

In the present study, we only collected one sample for each period of the year. As a result, some errors in the model calibration are inevitable. Because the model predicts values on a daily basis, some parameters such as water quality, $\mathrm{pH}$ and DO, will differ from the predicted values if the environmental conditions differ significantly from those at the time of sampling.

The water resources in our study area have not yet deteriorated severely. The lowest DOC values in the calibration and validation periods were 5.40 and $4.70 \mathrm{mg} . \mathrm{L}^{-1}$, respectively (Tables 4, 5), which are above the minimum concentration of $4.0 \mathrm{mg} . \mathrm{L}^{-1}$ established for the conservation of aquatic communities (Novotny, 2002). 


\subsection{Scenarios for protecting water quality}

In order to identify what strategies should be adopted to protect water quality in the study area, we developed several scenarios for changes in the model's input parameters during the dry period. We simulated changes in the water quality parameters along the Fidalgo stream to account for changes in the non-point-source flow rate and increased BOD and nutrient loads, and used the results to establish quality criteria for the protection of aquatic communities, according to international criteria recommended by USEPA, and to Brazilian criteria, recommended by CONAMA 357/2005.

These scenarios are based on the possible modification of non-point-source contributions resulting from human impacts within the watershed caused by the establishment of industrial and residential zones. Table 7 summarizes the proposed scenarios and the water quality results.
Considering the values adopted by USEPA, the limits for the TN and TP concentrations in the Fidalgo Stream are reached when the non-pointsource contribution increases by $0.12 \mathrm{mg} . \mathrm{L}^{-1}$ and $0.054 \mathrm{mg} . \mathrm{L}^{-1}$, respectively. These concentrations correspond to an increased load in the watershed amounting to only $0.022 \mathrm{~kg} . \mathrm{d}^{-1}$ of nitrogen and $0.010 \mathrm{~kg} . \mathrm{d}^{-1}$ of phosphorus. The $5.0 \mathrm{mg} \cdot \mathrm{L}^{-1} \mathrm{BOD}_{5}$ limit is reached when there is an increase in the non-point-source contribution of $2.00 \mathrm{mg} \cdot \mathrm{L}^{-1}$, which is equivalent to $0.361 \mathrm{~kg} \cdot \mathrm{d}^{-1}$. However, all simulations achieved the minimum required DOC concentration value.

The Brazilian CONAMA 357/05 do not establish limit values for TN. The limit for TP concentrations is reached when there is an increase in daily point-source contribution of $0.067 \mathrm{mg} . \mathrm{L}^{-1}$, which corresponds to an increment of $0.012 \mathrm{~kg} \cdot \mathrm{d}^{-1}$ in the phosphorus load in the watershed. The

Table 6. Root-mean-square errors (RMSE) for the measured values and model predictions during the calibration period (rainy season) and the confirmation period (dry season).

\begin{tabular}{|c|c|c|c|c|c|}
\hline \multirow[t]{3}{*}{ Parameter } & \multicolumn{5}{|c|}{ RMSE (\%) } \\
\hline & \multicolumn{2}{|c|}{ This study } & \multicolumn{2}{|c|}{ Kannel et al. (2007) } & \multirow{2}{*}{$\begin{array}{l}\text { Guedes et al. (2009) } \\
\text { Calibration }\end{array}$} \\
\hline & Calibration & Validation & Calibration & Validation & \\
\hline Flow rate & 4.64 & 5.42 & 4.0 & 3.6 & - \\
\hline pH & 1.18 & 2.77 & 7.0 & 17.7 & - \\
\hline EC & 0.85 & 2.81 & - & - & - \\
\hline TDS & 2.24 & 1.95 & - & - & - \\
\hline DOC & 6.87 & 7.90 & 15.0 & 19.2 & 10.8 \\
\hline $\mathrm{BOD}_{5}$ & 57.07 & 45.17 & 52.0 & 20.8 & 4.2 \\
\hline Organic nitrogen & 38.51 & 3.71 & - & - & - \\
\hline Ammonia nitrogen $\left(\mathrm{NH}_{3}\right)$ & 11.99 & 8.34 & - & - & - \\
\hline Nitrate nitrogen $\left(\mathrm{NO}_{3}\right)$ & 3.69 & 15.42 & - & - & - \\
\hline Total phosphorus (TP) & 1.66 & 3.37 & 31.0 & 42.0 & - \\
\hline Alkalinity & 2.04 & 2.73 & - & - & - \\
\hline E. coli count & 1.11 & 25.57 & - & - & - \\
\hline
\end{tabular}

Table 7. Water quality after accounting for increased non-point-source contributions in several scenarios.

\begin{tabular}{|c|c|c|c|c|}
\hline \multirow[t]{2}{*}{ Non-point-source increase } & \multicolumn{4}{|c|}{ Water quality results $\left(\mathrm{mg} \mathrm{L}^{-1}\right)$} \\
\hline & Min. DOC & Max. $\mathrm{BOD}_{5}$ & Max. TN & Max. TP \\
\hline Threshold value (USEPA) & 4.00 & 5.00 & 1.50 & 0.075 \\
\hline Threshold value (CONAMA 357/05 - class 2) & 5.00 & 5.00 & - & 0.1 \\
\hline BaseLine & 4.70 & 2.33 & 0.52 & 0.057 \\
\hline $1 \mathrm{~m}^{3} \cdot \mathrm{s}^{-1}$ flow $+2 \mathrm{mg} \cdot \mathrm{L}^{-1} \mathrm{BOD}_{5}$ & 5.53 & 4.97 & 1.39 & 0.058 \\
\hline $1 \mathrm{~m}^{3} \cdot \mathrm{s}^{-1}$ flow $+2 \mathrm{mg} \cdot \mathrm{L}^{-1} \mathrm{BOD}_{5}+0.12 \mathrm{mg} \cdot \mathrm{L}^{-1} \mathrm{TN}$ & 5.42 & 4.97 & 1.51 & 0.058 \\
\hline $1 \mathrm{~m}^{3} \cdot \mathrm{s}^{-1}$ flow $+2 \mathrm{mg} \cdot \mathrm{L}^{-1} \mathrm{BOD}_{5}+0.12 \mathrm{mg} \cdot \mathrm{L}^{-1} \mathrm{TN}+0.054 \mathrm{mg} \cdot \mathrm{L}^{-1} \mathrm{TP}$ & 5.42 & 4.97 & 1.51 & 0.075 \\
\hline $1 \mathrm{~m}^{3} \cdot \mathrm{s}^{-1}$ flow $+2 \mathrm{mg} \cdot \mathrm{L}^{-1} \mathrm{BOD}_{5}+0.6 \mathrm{mg} \cdot \mathrm{L}^{-1} \mathrm{TN}+0.12 \mathrm{mg} \cdot \mathrm{L}^{-1} \mathrm{TP}$ & 4.86 & 4.97 & 1.94 & 0.146 \\
\hline $1 \mathrm{~m}^{3} \cdot \mathrm{s}^{-1}$ flow $+5 \mathrm{mg} \cdot \mathrm{L}^{-1} \mathrm{BOD}_{5}$ & 5.49 & 7.94 & 1.39 & 0.058 \\
\hline $1 \mathrm{~m}^{3} \cdot \mathrm{s}^{-1} \mathrm{flow}+5 \mathrm{mg} \cdot \mathrm{L}^{-1} \mathrm{BOD}_{5}+0.12 \mathrm{mg} \cdot \mathrm{L}^{-1} \mathrm{TN}+0.054 \mathrm{mg} \cdot \mathrm{L}^{-1} \mathrm{TP}$ & 5.38 & 7.94 & 1.51 & 0.075 \\
\hline $1 \mathrm{~m}^{3} \cdot \mathrm{s}^{-1} \mathrm{flow}+5 \mathrm{mg} \cdot \mathrm{L}^{-1} \mathrm{BOD}_{5}+0.6 \mathrm{mg} \cdot \mathrm{L}^{-1} \mathrm{TN}+0.12 \mathrm{mg} \cdot \mathrm{L}^{-1} \mathrm{TP}$ & 4.80 & 7.94 & 1.94 & 0.146 \\
\hline
\end{tabular}


minimum of $5.00 \mathrm{mg} \cdot \mathrm{L}^{-1}$ for $\mathrm{BOD}_{5}$, the same as for the USEPA value, is reached when there is an increase in the non-point-source contribution of $2.00 \mathrm{mg} . \mathrm{L}^{-1}$, or $0.361 \mathrm{~kg} . \mathrm{d}^{-1}$. The DO concentration is lower than the limit of $5.00 \mathrm{mg} . \mathrm{L}^{-1}$ in the scenarios where there is an increase in the nitrogen and phosphorus loads by $0.022 \mathrm{~kg} . \mathrm{d}^{-1}$ and $0.010 \mathrm{~kg} . \mathrm{d}^{-1}$.

\section{Conclusions}

Our study showed that the QUAL2Kw model can adequately represent the physical, chemical, and hydraulic characteristics of the Fidalgo Stream watershed, but that increased sampling frequency would be necessary to improve calibration of the model.

In the study area, the changes in the surface water quality are mainly due to non-point-source pollution of rural origin and point-source pollution from the tributary that enters the stream. The results for the calibration (rainy period) modeling showed that the water quality at the spring (site S1) did not differ greatly from the downstream values for $\mathrm{pH}$ and DOC. However, the EC, $\mathrm{NH}_{3}$, TDS, TP, alkalinity, and $E$. coli count tended to be higher at the spring, and decreased with increasing distance from the spring. As the results for the validation (dry period) modeling, the water quality at the spring did not differ greatly from the downstream values for $\mathrm{pH}$ and $\mathrm{N}_{\text {org }}$. The EC, TDS, DOC, BOD, $\mathrm{NH}_{3}$, TP and alkalinity tended to be higher at the spring, and decreased with increasing distance from the spring.

The $\mathrm{pH}, \mathrm{EC}, \mathrm{TDS}, \mathrm{TP}$, alkalinity and E. coli presented the closest simulation values for the rainy period. For the dry period, the best simulations were obtained for $\mathrm{pH}, \mathrm{EC}, \mathrm{TDS}, \mathrm{TP}$ and alkalinity. It is likely that the ponds and lakes those have formed along the stream act as stabilization ponds and assist in the natural purification of the river.

Despite the population growth in the study region and the establishment of industrial and residential zones, the water resources have not yet deteriorated severely. The lowest DOC values in the calibration and validation periods were 5.40 and $4.70 \mathrm{mg} . \mathrm{L}^{-1}$, respectively, which are higher than the minimum of $4.0 \mathrm{mg} . \mathrm{L}^{-1}$ that has been proposed for the conservation of aquatic species. However, the BOD, TN, and TP limits for the protection of aquatic communities would be exceeded with additional non-point-source loads in the watershed of $0.361,0.022$, and $0.010 \mathrm{~kg} . \mathrm{d}^{-1}$, respectively. Managers should therefore adopt strategies to maintain inputs of BOD, TN, and TP below these limits. Preventive measures such as protecting exposed soils and decreasing the nutrient influx from agricultural or livestock activities should help managers to protect the fragile water resources of this karstic region.

\section{Acknowledgements}

We thank the Foundation for Research Support of the State of Minas Gerais - FAPEMIG for its financial support of our study.

\section{References}

American Public Health Association - APHA, American Water Works Association - AWWA, Water Pollution Control Federation - WPCF. 1995. Standard methods for the examination of water and wastewater. 21 th ed. Washington: APHA, AWWA, WPCF. 1600 p.

BIS, B., ZDANOWICZ, A. and ZALEWSKI, M. 2000. Effects of catchment properties on hydrochemistry, habitat complexity and invertebrate community structure in a Lowland River. Hydrobiologia, vol. 422-423, p. 369-387. http://dx.doi. org/10.1023/A:1017002923173

BROWN, LC. and BARNWELL JUNIOR, TO. 1987. The Enhanced Stream Water Quality Models QUAL2E and QUAL2E-UNCAS. Athens: USEPA, Environmental Research Laboratory. 204 p. EPA Document, no. 600/3-87/007.

BUTLER, D. and DAVIES, JW. 2004. Urban Drainage. 2th ed. London: Spon Press. 543 p.

CHANG, H. 2008. Spatial analysis of water quality trends in the Han River basin, South Korea. Water Research, vol. 42, p. 3285-3304. PMid:18490047. http://dx.doi.org/10.1016/j.watres.2008.04.006

CHAPRA, SC. and PELLETIER, GJ. 2003. QUAL2K: A Modeling Framework for Simulating River and Stream Water Quality (Beta Version). Medford: Civil and Environmental Engineering Department, Tufts University. 49 p. Documentation and Users Manual.

COX, BA. 2003. A review of currently available in-stream water-quality models and their applicability for simulating dissolved oxygen in lowland rivers. Science of the Total Environment, vol. 314-316, p. 335-377. http://dx.doi.org/10.1016/S0048-9697(03)00063-9

DROLC, A. and KONKAN, JZZ. 1996. Water quality modeling of the river Sava, Slovenia. Water Research, vol. 30, no. 11 , p. 2587-2592. http://dx.doi. org/10.1016/S0043-1354(96)00154-6

FU, G., BUTLER, D. and KHU, ST. 2008. The impact of new developments on river water quality from an integrated system modelling perspective. Scienceofthe Total Environment, vol. 407, p. 1257-1267. PMid:19036407. http://dx.doi. org/10.1016/j.scitotenv.2008.10.033

GUEDES, HAS., DA SILVA, DD., OLIVEIRA, IC., RIBEIRO, CBM. and ELESBON, AAA. 2009. 
Estudo da capacidade de autodepuração do rio Pomba utilizando o modelo QUAL2Kw. In Anais XVIII Simpósio Brasileiro de Recursos Hidricos, 2009. Campo Grande: ABRH. 1 CD-ROM.

JONES, EBD., HELFMAN, GS., HARPER, JO. and BOLSTAD, PV. 1999. Effects of riparian forest removal on fish assemblages in Southern Appalachian streams. Conservation Biology, vol. 13, no. 6, p. 1454-1465. http://dx.doi.org/10.1046/j.15231739.1999.98172.x

KANNEL, PR., LEE, S., KANNEL, SR., LEE, Y. and AHN, KH. 2007. Application of QUAL2Kw for water quality modeling and dissolved oxygen control in the river Bagmati. Environmental Monitoringand Assessment, vol. 125, p. 201-217.

KOHLER, HC. 1989. Geomorfologia Cárstica na Região de Lagoa Santa - MG. São Paulo: Universidade de São Pulo. [Tese de Doutorado em Geografia].

LIMA, JP. 2005. Parâmetros de qualidade de águas superficiais. Portugal: Universidade de Coimbra. Nota de aula: Introdução à Engenharia do Ambiente - Folha 2: Poluição hídrica.

LIMBURG, KE. and SCHMIDT, RE. 1990. Patterns of fish spawning in Hudson River tributaries: response to an urban gradient. Ecology, vol. 71, no. 4, p. 1238-1245. http://dx.doi.org/10.2307/1938260

NOVOTNY, V. 2002. Water Quality: Diffusion Pollution and Watershed Management. 2th ed. New Jersey: John Wiley \&Sons, Inc., Hoboken. 888 p.

OLIVERA, F. and DEFEE, BB. 2007. Urbanization and its effect on runoff in the Whiteoak Bayou watershed, Texas. Journal of American Water Research Association, vol. 43, no. 1, p. 170-182. http://dx.doi. org/10.1111/j.1752-1688.2007.00014.x

PELLETIER, GJ. and CHAPRA, CS. 2005. QUAL2Kw theory and documentation: A Modeling Framework for Simulating River and Stream Water Quality.
Version 5.1. Available from: <http://www.ecy.wa.gov/ programs/eap/models/>. Access in: 7 apr. 2010.

PELLETIER, GJ., CHAPRA, CS. and TAO, H. 2006. QUAL2Kw, A framework for modeling water quality in streams and rivers using a genetic algorithm for calibration. Environmental Modelling and Software, vol. 21, p. 419-425. http://dx.doi.org/10.1016/j. envsoft.2005.07.002

RIVA-MURRAY, K., BODE, RW., PHILLIPS, PJ. and WALL, GL. 2002. Impact source determination with biomonitoring data in New York State: concordance with environmental data. Northeastern Naturalist, vol. 9, no. 2, p. 127-162.

SILVA, MDFM., CALIJURI, ML., COUTO, EA. and CAMARGO, RA. 2010. Zoneamento ambiental do entorno do aeroporto internacional Tancredo Neves, APA Carste de Lagoa Santa -MG. In Anais XXIV Congresso Brasileiro de Cartografia, 2010. Aracajú: SBC.

TUCCI, CEM. 1998. Modelos Hidrológicos. Porto Alegre: Ed. UFRGS. 652p.

U.S. Geological Survey - USGS. 1974. Methods for collection and analysis of water samples for dissolved minerals and gases. Washington: U.S. Geological Survey. 160 p. Techniques of Water-Resources Investigations.

Von SPERLING, M. 2007. Princípios do tratamento biológico de águas residuárias. Belo Horizonte: DESAUFMG. vol. 7. Estudos e modelagem da qualidade da água de rios, $588 \mathrm{p}$.

WILLIAMS, PW. 1993. Environmental change and human impact on karst terrains: an introduction. Catena Supplement, vol. 25, p. 1-19.

WOODCOCK, T., MIHUC, T., ROMANOWICZ, E. and ALLEN, E. 2006. Land-use effects on catchment - and patch - scale habitat and macroinvertebrate response in the Adirondack Uplands. American Fisheries Society symposium, vol. 48, p. 395-411.

Received: 23 February 2011 Accepted: 30 June 2011 